\title{
Ordforklaringer
}

Fitness: En organismes evne til overlevelse og reproduksjon.

Metabolske kostnader ved resistens: Antibiotikaresistente bakterier vokser ofte saktere enn sine følsomme slektninger (resistens reduserer «fitness»). Dersom antibiotikaforbruket så elimineres, vil de følsomme bakteriene i en populasjon utkonkurrere de resistente. I teorien vil da antibiotikaresistensen forsvinne.

Redusert resistensbyrde: Antibiotikaresistente bakterier kan tilpasse seg resistenstilstanden ved å redusere de meta-

Tre av artikkelforfatterne. Fra venstre Kaare M. Nielsen, Pål J. Johnsen og Gunnar S. Simonsen. Foto Thomas Bøhn

\section{Er antibiotikaresistens reverserbart?}

\author{
Reversering av antibiotikaresistens er påvirket av mange faktorer. \\ Nå har forskere i Troms $\varnothing$ sett på disse faktorene i detalj.
}

Det er en utbredt oppfatning at antibiotikaresistensen økes gjennom bruk av antibiotika og reduseres når forbruket går ned.

Reverseringen er en komplisert prosess som avhenger av en rekke biologiske faktorer hos mikroorganismene. I en nylig publisert oversiktsartikkel i Lancet Infectious Diseases gjennomgås disse faktorene i detalj (1).

- Vi setter spesielt søkelyset på evolusjonære mekanismer i bakteriepopulasjonene, som metabolske kostnader ved resistens, seleksjon og bakterienes evne til å redusere resistensbyrdene, sier førsteforfatter Pål Jarle Johnsen ved Institutt for farmasi, Universitetet i Tromsø.

- Overvåkningsdata fra norsk og dansk landbruk er brukt for å illustrere at selv ved totalt fravær av antibiotikaseleksjon kan resistente bakterier persistere i miljøet over svært lang tid. Datagrunnlaget er delvis hentet fra NORM og NORM-VET, som er de norske overvåkingssystemene for antibiotikaresistens hos mikrober fra mennesker og innen veterinærmedisinen.

\section{Forbudt fôrtilskudd}

I Norge har man fulgt utviklingen etter at all bruk av glykopeptidantibiotikumet avoparcin som fôrtilskudd ble stanset i 1995. Resultatene viser at selv etter 12 år er fortsatt ca. $1 \%$ av bakteriene resistente mot avoparcin og vankomycin. Vi forsøker å forklare dette, særlig med bakgrunn i Tromsø-miljøets og samarbeidspartnernes arbeider de siste ti år.

Konklusjonen er at antibiotikaresistens lett vil oppstå og selekteres for i bakteriepopulasjonene ved bruk av antibiotika, og at det er desto vanskeligere å eliminere resistensen når den først har oppstått. Konsekvensen er at resistens mot et gitt anti- mikrobielt middel raskt vil øke til tilsvarende nivå som fra før forbruket ble eliminert dersom bruken blir gjenopptatt, sier Johnsen.

\section{Forskning på antibiotikaresistens}

Artikkelen er et resultat av et pågående samarbeid mellom mikrobiologimiljøene ved Universitetet i Tromsø, Mikrobiologisk avdeling ved Universitetssykehuset NordNorge, GenØk senter for biosikkerhet og Yale University, USA.

I det tverrfaglige samarbeidet legges det vekt på evolusjonære mekanismer som påvirker reverseringen av antibiotikaresistens i bakteriepopulasjoner, og man benytter seg av eksperimentelt laboratoriearbeid og matematisk modellering. Forfatterne av artikkelen er Pål Jarle Johnsen, Jeffrey P. Townsend, Thomas Bøhn, Gunnar Skov Simonsen, Arnfinn Sundsfjord og Kaare M. Nielsen.

\section{Erlend Hem \\ erlend.hem@medisin.uio.no \\ Tidsskriftet \\ Litteratur \\ 1. Johnsen PJ, Townsend JP, Bøhn T et al. Factors affecting the reversal of antimicrobial-drug resis- tance. Lancet Infect Dis 2009: 9: 357-64.} såkalt adaptive mutasjoner som (helt eller delvis) gjenoppretter funksjonen i genprodukter som påvirkes av resistensmekanismen(e). Resultatet blir i beste fall at i fravær av antibiotikaseleksjon vil det ta lengre tid før resistensen reverseres. Ved full gjenoppretting av funksjonen er det ikke lenger noen forskjell $i$ «fitness» mellom følsomme og resistente bakterier, og reversering av resistens grunnet konkurranse fra følsomme bakterier vil i teorien ikke skje.

Artikkelen ble publisert i juninummeret 2009 av Lancet Infectious Diseases, som er det høyest rangerte tidsskriftet innen infeksjonssykdommer

\section{Tips oss}

Er du iferd med å publisere eller har du nylig publisert iet internasjonalt tidsskrift? Send tips til erlend.hem@medisin.uio.no 